\title{
Zombie Firms and Economic Stagnation in Japan
}

\author{
Alan G. Ahearne and Naoki Shinada*
}

October 2004

\begin{abstract}
Prepared for CGP Program Part (2) conference, Macro/Financial Issues and International Economic Relations: Policy Options for Japan and the United States Ann Arbor, October 22/23, 2004.
\end{abstract}

\begin{abstract}
* Ahearne: Division of International Finance, Board of Governors of the Federal Reserve System, alan.g.ahearne@frb.gov. Shinada: Development Bank of Japan, nashina@dbj.go.jp. The views in this paper are solely the responsibility of the authors and should not be interpreted as reflecting the views of the Development Bank of Japan, the Board of Governors of the Federal Reserve System or of any other person associated with the Federal Reserve System.
\end{abstract}




\begin{abstract}
It is often claimed that one contributing factor to Japan's weak economic performance over the past decade is that Japanese banks have continued to provide financial support for highly inefficient, debt-ridden companies, commonly referred to as "zombie" firms. Such poor banking practices in turn prevent more productive companies from gaining market share, strangling a potentially important source of productivity gains for the overall economy. To explore further the zombie-firm hypothesis, we use industry- and firm-level Japanese data and find evidence that productivity growth is low in industries reputed to have heavy concentrations of zombie firms. We also find that the reallocation of market share is going in the wrong direction in these industries, adding to already weak productivity performance. In addition, we find evidence that financial support from Japanese banks may have played a role in sustaining this perverse reallocation of market share.
\end{abstract}

Keywords: Productivity, banking system, creative destruction. 


\section{Introduction}

It is often claimed that one factor contributing to Japan's economic weakness over the past decade is that Japanese banks have continued to provide financial support for highly inefficient, debt-ridden companies, commonly referred to as "zombie" firms. ${ }^{1}$ Measured productivity growth of these firms has tended to be very low or even negative for many years, putting a significant drag on the productivity performance of the Japanese economy. Moreover, zombie firms prevent more productive companies from gaining market share, strangling a potentially important source of productivity gains for the overall economy. In this paper, we use industry- and firm-level data to explore this zombie-firm hypothesis, focusing on the construction and retailing industries, which are reputed to have heavy concentrations of such firms.

At the industry level, we find significant differences in productivity performance between traded- and non-traded-goods sectors. Industries in which competitive pressures are most intense, such as export-oriented sectors, tend to perform relatively well. In contrast, industries where competition is suppressed--and where zombie firms reputably are prominent--display weak productivity growth. Focusing on these poorly performing industries, we use firm-level data to provide evidence that the reallocation of market share is going in the wrong direction, adding to already poor productivity performance. Moreover, it appears that highly inefficient firms are being sustained in large part by financial support from Japanese banks. In turn, these poor banking practices are likely contributing to problems in the Japanese banking sector (see, for example, Smith [2003]).

\footnotetext{
${ }^{1}$ See, for example, Caballero, Hoshi and Kashyap (2003), Caballero and Kashyap (2002), The Economist (2004), Feldman (2002), and Lincoln (2001).
} 
The rest of the paper is structured as follows. In the next section, we present some estimates of recent productivity growth in Japan, both at an aggregate and industry level. The third section summarizes a simple theoretical model of creative destruction, in which the banking system is assigned a critical role in reallocating resources to their most efficient use. The fourth section presents empirical evidence on the sources of low productivity growth and the allocation of bank credit in a range of industries based on firm-level data. The final section outlines the policy implications of our results.

\section{Productivity Performance}

Table 1 reports results of a standard growth accounting exercise applied to Japanese GDP. ${ }^{2}$ Of the sharp slowdown in real GDP growth since the early 1990s, half can be attributed to a drop in labor input. Notably, average weekly hours worked, shown in Figure 1, has fallen sharply over the past decade reflecting reduced demand for labor in the face of sluggish aggregate spending, as well as a legislative effort to shorten the workweek. ${ }^{3}$ The working-age population, also shown in Figure 1, peaked during the mid-1990s. With the working-age population projected to shrink further, labor input will likely remain a constraint on growth, absent a change in immigration policy or a substantial increase in the workforce participation rate.

\footnotetext{
${ }^{2}$ The results in Table 1 are based on a standard framework for growth-accounting analysis, where labor productivity growth is measured as the difference between the growth of output and the growth of the number of hours worked. Multifactor productivity growth is measured as the difference between output growth and total input growth. This measure, also known as the Solow residual, reflects the influence of technological change not already embodied in new capital. This residual also reflects measurement errors and cyclical factors not captured elsewhere. Total input growth is measured as a weighted average of labor hours growth and capital growth. The weight for labor is this factor's income share; one minus the share of labor is the weight of capital. Finally, we decompose the growth of labor productivity into the growth of multifactor productivity and the contribution of capital deepening.

${ }^{3}$ This effort to shorten the traditionally long Japanese workweek included a gradual reduction in the statutory workweek from 6 to 5 workdays per week beginning in 1988. In addition, the number of national holidays was increased by 3 during this period. See Hayashi and Prescott (2002) for more details.
} 
$<$ Table 1 about here $>$

GDP also slowed because of a deceleration in labor productivity. Had it not been for a continued sizable contribution from capital deepening, labor productivity growth would have declined even more sharply, given the pronounced deceleration of multifactor productivity, some of which likely reflects falling rates of input utilization. ${ }^{4}$ However, it is not clear how long capital accumulation will continue to provide such sizable support for labor productivity. As shown in Figure 2, although Japanese private investment has fallen sharply as a share of GDP since the late 1980s, the capital-output ratio has continued to rise, suggesting that Japanese firms may still be over-investing.

$<$ Figures 1 and 2 about here $>$

Table 2 provides a cross-industry perspective on productivity growth in Japan. Growth in labor productivity in the manufacturing sector has slipped since the 1980s. Some export-oriented industries, such as chemicals, electrical machinery, and transport equipment have continued to perform reasonably well, spurred by exposure to competition in the global marketplace. In contrast, the productivity record of non-tradedgoods and services industries, such as construction, and wholesale and retail trade has been poor of late. It is widely believed that competitive pressures in these industries are weak, suppressed by cartels, excessive government regulation, and other market

\footnotetext{
${ }^{4}$ Kawamoto (2004) shows evidence that the slowdown in multifactor productivity in Japan in the 1990s largely reflects lower cyclical utilization of capital and labor and reallocation of inputs rather than a change in the rate of technical progress.
} 
distortions. ${ }^{5}$ Moreover, the near absence of FDI in Japan suggests there is little foreign competition to goad productivity gains in Japan's non-traded-goods sectors.

$<$ Table 2 about here $>$

Sectors such as construction, real estate, and wholesale and retail trade, which expanded rapidly in the 1980s, were hard hit by the bursting of the bubble in the early 1990s. Nevertheless, as shown in Figure 3, these industries retained largely undiminished access to bank credit through the 1990s. Bank loans to the construction sector have not declined much from the peak in the mid-1990s, although the value of the land that serves as collateral for many of these loans has plummeted.

$<$ Figure 3 about here $>$

Liabilities of non-manufacturing firms rose rapidly relative to cash flows during most of the 1990s. Liabilities have recently eased back some as firms have made an effort to repay debt. Nonetheless, liabilities remain well above the target ceiling of 10 times cash flow that many commentators regard as the dividing line between viable and non-viable firms. Liabilities are especially high--over 20 times cash flow--in industries such as construction, real estate, and wholesale distribution sectors.

Figure 4 further highlights the differences between traded- and non-traded-goods sectors by decomposing changes in labor productivity for selected industries into changes

\footnotetext{
${ }^{5}$ See Porter, Takeuchi and Sakakibara (2000) and Katz (1998) for extensive discussions of possible reasons why some Japanese industries are highly competitive, while other industries exhibit very poor productivity growth.
} 
in multifactor productivity and the contribution of capital deepening. The performance of multifactor productivity has been far better in the traded-goods industries than in the nontraded-goods industries, with the construction sector performing especially poorly.

$<$ Figure 4 about here $>$

\section{Model of Creative Destruction}

The theoretical literature has suggested channels through which zombies firms can contribute to low aggregate productivity growth: (1) zombie firms themselves exhibit low or even negative rates of firm-level productivity growth. In part, some of this poor firm-level productivity performance likely reflects falling rates of input utilization; and (2) zombie firms prevent more productive companies from gaining market share, strangling a potentially important source of productivity gains for the overall economy. For example, using data on U.S. manufacturing industries, Foster et al. (1998) find that output reallocation across production sites makes a large contribution to industry-level multifactor productivity growth. ${ }^{6}$ This second channel is closely tied to the Schumpeterian notion of "creative destruction," whereby the development of new products and the adoption of more efficient production processes requires the destruction of old products and outdated production techniques.

Central to the proper working of the creative-destruction process are market forces that compel poorly performing firms to restructure, or in some cases cease operations. For example, profit-maximizing banks and other financial intermediaries would normally be expected to withdraw credit from poorly performing firms, putting

\footnotetext{
${ }^{6}$ See also Davis and Haltiwanger (1999) and Haltiwanger (2000).
} 
pressure on such firms to improve efficiency or close down. Credit would then be reallocated to more innovative firms or to potentially productive start-up companies, allowing these firms to expand. In Japan, however, there is evidence that banks continue to roll over loans to zombie firms. Many of these loans are de facto nonperforming, and foreclosing on such credits would force banks to recognize large losses. Most analysts believe that banks have inadequately provisioned against such losses. As a result, foreclosing on loans to zombie firms would wipe out much of banks' capital, with negative consequences for bank shareholders and management. By continuing to provide financial support to troubled borrowers, however, banks are hindering the proper functioning of the creative-destruction process.

To fix ideas, consider the following model of creative destruction, which is based on Atkeson and Kehoe (1995). In this model, there is a continuum of firms, and each firm is operated by a manager. Assume that firm $j$ produces according to the production function

$$
y_{j t}=z_{j t}^{1-v}\left(k_{j t}^{\alpha} l_{j t}^{1-\alpha}\right)^{v}
$$

where $l_{j t}$ is labor input, $k_{j t}$ is capital, and $z_{j t}$ is firm-level multifactor productivity. This functional form allows for diminishing returns at the firm level. A manager who decides to operate a plant chooses $l_{j t}$ and $k_{j t}$ each period to maximizes profits

$$
\phi_{j t}=y_{j t}-r_{t} k_{j t}-w_{t} l_{j t}-w_{j t}^{m}
$$


where $w_{j t}^{m}$ is the manager's opportunity cost of not working or starting another firm. Let the solutions be denoted $k_{t}\left(z_{j}\right)$ and $l_{t}\left(z_{j}\right)$. For a given distribution $\lambda_{t}\left(z_{j}\right)$ of firm-level productivities, it is easy to show that aggregate output is given by

$$
Y_{t}=Z_{t}^{1-v} K_{t}^{\alpha} L_{t}^{1-\alpha}
$$

where

$$
Z_{t}=\int_{z_{j}} z_{j t} \lambda_{t}\left(d z_{j}\right)
$$

is aggregate productivity, and

$$
\begin{aligned}
& K_{t}=\int_{z_{j}} k_{t}\left(z_{j}\right) \lambda_{t}\left(d z_{j}\right) \\
& L_{t}=\int_{z_{j}} l_{t}\left(z_{j}\right) \lambda_{t}\left(d z_{j}\right)
\end{aligned}
$$

are aggregate capital and labor, respectively. It is clear from equation (4) that aggregate productivity depends on the mean of the productivities of all of the firms that are in operation.

Firm-level productivity is an idiosyncratic random variable, which evolves over time according to the following rule: a firm with productivity $z_{j}$ at time $t$ has random productivity $z_{j} \varepsilon$ at time $t+1$, where the shock $\varepsilon$ is drawn from a probability distribution $\pi(\varepsilon)$. A manager's decision whether to operate a firm is described by the Bellman equation

$$
V_{t}\left(z_{j}\right)=\max \left[0, V_{t}^{O}\left(z_{j}\right)\right]
$$

where 


$$
V_{t}^{o}\left(z_{j}\right)=\max \left[y_{j t}-r_{t} k_{j t}-w_{t} l_{j t}-w_{j t}^{m}\right]+\frac{1}{1+R_{t}} \int_{\varepsilon} V_{t+1}\left(z_{j} \varepsilon\right) \pi(\varepsilon)
$$

Here, $R_{t}$ is the interest rate, $V_{t}^{O}\left(z_{j}\right)$ is the (maximum) return from operating a firm in the current period, and $V_{t}\left(z_{j}\right)$ is the maximum of the returns from either closing the plant or operating it. New plants can enter according to a similar process. The outcome of all the managerial decisions to operate or not is a new distribution $\lambda_{t+1}\left(z_{j}\right)$ over productivities in period $t+1$.

Next, assume that the probability distribution that generates the shocks to firmlevel productivity, $\pi(\varepsilon)$, changes with plant age. In particular, assume that the mean value of shocks to the productivity of a firm gradually increases over the course of a certain number of years, and then begins to decline. The purpose of this feature is to capture "learning-by-doing" effects, where firms learn over time how to most efficiently use the newest technology. Eventually, this learning process slows down.

For simplicity, assume that there are only two firms in the economy, firm 1 and firm 2. Suppose that firm 1 is a zombie firm, and banks lend to firm 1 at a subsidized interest rate, $R_{1 t}=\hat{R}_{t}\left(1-\tau_{1 t}\right)$. In contrast, banks are assumed to lend to firm 2, a "normal" firm, at a relatively high interest rate, $R_{2 t}=\hat{R}_{t}\left(1+\tau_{2 t}\right)$. It is clear that the zombie firm will discount the future less than the normal firm. Substituting these distorted interest rates into equation (8) produces different solutions to the managers' dynamic programming problems for firms 1 and 2. In particular, the zombie firm will choose to continue to operate in situations where the normal firm would choose to shut down. Even if a zombie firm experiences a low productivity shock, it will be more prone to borrow to cover losses and to continue operating, hoping for a favorable shock to 
increase its productivity in the future. In an economy with many zombie firms and many normal firms, this behavior changes the mix of firms that operate, leading to inefficiently many low-productivity firms continuing. This leads to a lower value of aggregate productivity.

\section{Empirical Evidence}

To investigate further the sources of low productivity growth in Japan, we use firm-level data to study a range of industries. Our data are from the Corporate Finance Database of the Development Bank of Japan, which contains detailed financial-statement data on all companies listed on Japanese stock exchanges. The data cover the period from 1970 to 2001. However, mirroring the analysis of aggregate productivity in Section II, we will our focus our attention on the stark contrast in productivity performance in the 1980s compared with the 1990s. Our sample includes 604 firms from which data are reported in every year over the entire sample period. These firms are classified into 33 different industry groups. However for a number of groups our dataset contains only a small number of firms. As a result, we limit our analysis to a selected set of industries for which we have a sufficient number of firms. ${ }^{7}$

For each firm, we calculate firm-level value added and multifactor productivity (MFP) using the methodology described below. Shinada (2003) provides a more detailed presentation of our data and methods for calculating firm-level productivity.

Assume firm $j$ produces real output $y_{j t}$ according to the Cobb-Douglas function

\footnotetext{
${ }^{7}$ In particular, our dataset contains only two firms in the real estate industry. Presumably, many Japanese real estate firms are not listed on Japanese stock exchanges and are therefore not included in the Development Bank of Japan's Corporate Finance Database. In addition, we suspect that several listed firms that are involved in real estate are included in our dataset under the "construction" or "other construction" groupings. Both these industry groupings are included in our sample.
} 


$$
y_{j t}=z_{j t} k_{j t}^{\alpha} l_{j t}^{(1-\alpha)}
$$

where $l_{j t}$ is labor input (hours worked), $k_{j t}$ is real capital, and $z_{j t}$ is multifactor productivity (MFP). Taking natural logarithms of the production function and rearranging terms, we measure firm-level MPF as the difference between real output and total inputs

$$
\ln z_{j t}=\ln y_{j t}-\alpha \ln k_{j t}-(1-\alpha) \ln l_{j t}
$$

Real output is defined as firm nominal value added deflated by a wholesale price index defined at the industry level. The common approach in recent work on firm-level MPF is to calculate value added by subtracting intermediate inputs from gross output. Unfortunately, our data set does not report data on intermediate inputs. The data set, however, does contain information on factor incomes, which we use to construct a measure of nominal firm-level value added (at factor cost): nominal value added $=$ expenditures on labor + rental expenses + depreciation expenses + operating profits (before interest $)+$ taxes and public charges + patent license fees.

Labor input is measured by the total hours worked at each firm, calculated as the number of workers multiplied by the average number of hours worked. The number of workers is the total number of employees of each firm at the end of the period, excluding temporary and contract workers. Average hours worked is estimated using industry indexes of working hours from the Monthly Labor Survey conducted by the Ministry of Health, Labor and Welfare.

To calculate capital input, we separate capital stocks into (1) depreciable assets, (2) real estate, and (3) inventory assets. For depreciable assets, we assume that the flow 
of capital services is proportional to the stock of capital. Our methodology for measuring firm-level capital stock is based on the law of motion

$$
k_{j t+1}=(1-\delta) k_{j t}+x_{j t}
$$

where $x_{j t}$ is real gross investment and $\delta$ is the depreciation rate.

The depreciation rates are set to correspond to the rates reported by Hayashi and Inoue (1991) and Nagahata and Sekine (2002). We set the elasticity of output with respect to capital equal to the industry-level share of capital, calculated as one minus the share of labor.

We estimate $x_{j t}$ by deflating nominal gross investment by the price of capital goods. Nominal gross investment is measured using the reported cost of new tangible fixed assets. Wholesale price indexes for capital goods are then used to deflate nominal investment. We take 1970 as our base year and estimate the real capital stock by industry. Real net capital stock by industry is estimated based on the National Accounts and Price Sector Corporate Capital Stock of the Cabinet Office. The book value of tangible fixed assets of non-financial corporations from the Annual Report of Corporate Statistics is used for capital stock book value by industry. The real net capital stock of each firm was then estimated by determining the market value/book value ratio by industry in 1970 using the above data and multiplying that by the asset book price of each company in 1970. See Shinada (2003) for further details.

Aggregating across all firms in industry $i$, we calculate the growth of industry output and inputs. Table 3 shows the results of these calculations for a range of industries that contain a sufficiently large number of firms. As in the industry-level analysis presented in Section II, labor productivity slowed in the 1990s compared with 
the 1980s in almost all industries (line 3 of each industry table). The slowdown was much more pronounced in industries in the non-traded-goods sector, particularly construction (Table $3 \mathrm{~h}$ and 3i) and transport (Table 31). Export-oriented sectors such as chemicals, transport equipment, and electrical machinery (Tables 3a to 3c) continued to record robust rates of labor productivity in the 1990s, though the pace slowed a bit from the previous decade. Labor productivity actually accelerated in the precision machinery industry (Table 3d). The performances of several other manufacturing sectors were more mixed, including food production (which is largely domestically oriented) and textiles (which experienced a mass migration of production facilities to China.)

One point worth noting about the estimates of labor productivity growth constructed from firm-level data and presented in Table 3 is that they are broadly similar to the estimates from industry-level data shown in Table 2. This suggests that we can be reasonably confident that the firms in our sample are relatively representative of the larger population. That said, for several industries, labor productivity growth based on our dataset of firms is faster than the estimate based on aggregate data, probably reflecting the fact that our sample of firms consists of only listed companies, and therefore excludes many small- and medium-sized firms that may have performed especially poorly in the 1990s.

In the traded-goods sectors, the slowdown in labor productivity largely reflected a marked retrenchment in capital spending, while multifactor productivity growth held up well or even increased. In contrast, in the non-traded sector the 1990s was generally associated with sluggish multifactor productivity growth, included a slump in productivity in sub-sectors of the construction industry. 
$<$ Table 3 about here $>$

How much of this slow in productivity in the 1990s in the non-traded industries reflects poor performance within individual firms, and how much is because of changes in market share? To answer this question, we follow Haltiwanger (1997) and define industry productivity as the market-share weighted sum of the firms' productivity levels

$$
\ln Z_{i t}=\sum_{j \in I} \theta_{j t} \ln z_{j t}
$$

where $I$ is the set of firms in industry $i$, and $\theta_{j}$ is firm $j$ 's share of nominal sales in industry $i$. Growth in industry productivity between periods $t-k$ and $t$ is given by

$$
\Delta \ln Z_{i t}=\ln Z_{i t}-\ln Z_{i t-k}
$$

Next, we decompose changes in industry productivity into several terms

$$
\Delta \ln Z_{i t}=\sum_{j \in I}\left(\theta_{j t-k} \Delta \ln Z_{j t}\right)+\sum_{j \in I}\left(\ln Z_{j t-k}-\ln Z_{i t-k}\right) \Delta \theta_{j t}+\sum_{j \in I}\left(\Delta \theta_{j t} \Delta \ln Z_{j t}\right)
$$

The first term, which we refer to as the "within" firm component, measures what would have happened to industry productivity as a result of changes in productivity within individual firms, had market shares stayed constant. It is calculated as the sum across all 
firms in the industry of each individual firm's own productivity growth, weighted by the firm's initial market share. The second term, the "between" firm component, measures the additional impact on industry productivity due to changes in market shares. It is calculated by summing changes in each firm's market share, weighted by the deviation of initial firm productivity from the initial industry productivity. The third term is a covariance component. Industry productivity would rise (fall) if: (1) individual firm productivity increased (decreased), or (2) if there was a reallocation of market share from low (high) productivity to high (low) productivity firms, or (3) if there was a reallocation of market share to firms with rapidly rising (falling) productivity ${ }^{8}$.

\section{$<$ Table 4 about here $>$}

The results of this decomposition for the industries in our sample are reported in Table 4. Note that the estimates of multifactor productivity growth reported in Table 4 differ somewhat from those in Table 3. These differences arise because firms are weighted by nominal sales in the construction of industry aggregates in Table 4 , whereas in Table 3 aggregates are calculated by (implicitly) weighting firms by value added. In most cases the differences are modest, and both sets of estimates paint the same qualitative picture of multifactor productivity growth across industries: Multifactor productivity growth held up well or even increased in the 1990s in traded-goods sectors, while growth in non-traded sectors generally was sluggish and often declined.

\footnotetext{
${ }^{8}$ Because we use a balanced panel of firms for our analysis, we do not include exit and entry terms in our decomposition. In part, our decision to use a balanced panel reflects the difficulty of interpreting firm "entry" in a dataset of listed firms. For example, many firms operate for considerable periods of time prior to being listed on a stock exchange. In addition, there are technical reasons associated with our method for computing firms' real capital stocks that render the use of an unbalanced panel highly problematic.
} 
Focusing on Table 4 , of the roughly $1 / 2$ percent rate of average annual decline in multifactor productivity over the 1990s in the civil engineering sub-sector of the construction industry (Table $4 \mathrm{~h}$ ), roughly one half resulted from falling productivity within firms. The remainder resulted from gains in market share by less productive firms at the expense of firms with higher or more rapidly growing levels of productivity. ${ }^{9}$ Multifactor productivity growth in other construction sectors (Table 4i) crawled to a standstill in the 1990s, as the contribution from productivity growth within firms slowed from $2 \frac{1}{2}$ percentage points in the 1980 s to $3 / 4$ percentage point in the 1990 s. In addition, the contribution from the reallocation of market share turned from a positive rate of roughly $1 / 4$ percentage point in the 1980 s to a negative contribution of $1 / 2$ percentage point in the 1990s. One possible explanation for this perverse reallocation of market share is that banks continued to make loans to inefficient firms. In addition, many such firms are reportedly closely connected with the ruling Liberal Democratic Party and continued to bid successfully for public works projects. ${ }^{10}$

In the retail trade sector (Table $4 \mathrm{j})$ and the wholesale trade sector (Table $4 \mathrm{k})$, multifactor productivity growth slowed some in the 1990s. In the retail trade sector, this slowdown occurred despite a larger contribution from rising productivity within firms. In both sectors, the contribution from the reallocation of market share, which was already negligible in the 1980s, turned slightly negative in the 1990s.

Similarly, the cargo road transport sector (Table 41) saw the contribution from the reallocation of market share turn negative in the 1990s, resulting in a decline in multifactor productivity.

\footnotetext{
${ }^{9}$ These results are consistent with the findings in Nishimura, Nakajima and Kiyota (2004) that efficient firms exited the Japanese economy while inefficient ones survived during the banking crisis of 1996-1997. ${ }^{10}$ See Ahearne et al. (2002) for a review of Japanese fiscal policy during the 1990s.
} 
In contrast, the contributions to productivity growth from the reallocation of market share in traded industries such as chemicals, transport equipment, and electrical machinery (Table $4 a, 4 b$, and $4 c$, respectively) showed little change over the two decades. In these industries, the reallocation of market share continued to make contributions of between $1 / 2$ to 1 percentage points to average annual growth in multifactor productivity. In the precision machinery industry (Table $4 \mathrm{~d}$ ), performance of multifactor productivity improved markedly in the 1990s, in part resulting from a swing to a positive contribution from the reallocation of market share.

The results above are consistent with the zombie-firm hypothesis: During the 1990s, inefficient zombie firms in Japan's non-traded-goods sectors appear to have prevented more productive companies from gaining market share. In the remainder of this section, we use firm-level data from the Corporate Finance Database on borrowing from banks by the firms in our sample to try to ascertain whether financial support from Japanese banks may have played a role in sustaining this perverse reallocation of market share. Peek and Rosengren (2003) find that Japanese firms are far more likely to receive additional bank credit if they are in poor financial condition, and that troubled Japanese banks allocate credit to severely impaired borrowers primarily to avoid the realization of losses on their own balance sheets.

Figure 5 shows total outstanding borrowing from banks aggregated by industry. Total borrowings are calculated as the sum of short-term borrowings, current portion of long-term borrowings (which will be paid back within a year), and long-term borrowings (which will be paid back two or more years later). Many industries show a rapid run-up in borrowing from banks during the bubble period of the late 1980s. In traded-goods 
sectors such as chemicals, electrical machinery, and transport machinery borrowing peaked in the early 1990s, before declining sharply throughout much of the decade. In contrast, total borrowing from banks by firms in non-traded-goods sectors such as construction (other), retail trade, and wholesale trade rose sharply during the 1990s, before turning down in 2000 and 2001 . The outcome is that relatively poorly performing industries were increasing their share of total borrowing from banks relative to better performing sectors.

In part, the patterns during the 1990s described above may reflect an increasing proclivity of firms in traded-goods sectors to tap capital markets directly, allowing them to reduce their reliance on banks as sources of finance. In addition, Japanese banks may have been reluctant to cut off lending to poorly performing firms in the non-traded-goods sectors because such actions may have required that the banks be recapitalized.

The results in Table 5 provide additional evidence of misallocation of credit by banks in Japan. Based on our firm-level data, Table 5 shows the correlation between changes in market share and changes in the share of outstanding loans from banks. For example, in the chemicals industry, we find a strong positive correlation (0.75) over the period 1980-1990, meaning that firms that gained market share over this period also tended to increase their share of total bank loans to the chemical industry. Most other industries also showed positive correlations over this period.

In the 1990s, however, correlations in traded-goods industries such as transport equipment, electrical machinery, and precision machinery swung into highly negative territory, and the correlation in the chemicals sector dropped to near zero. These swings are consistent with better performing firms in these sectors increasingly tapping capital 
markets directly (and hence borrowing less from banks) while gaining market share. In contrast, in zombie-laden sectors such as construction, retail trade, and wholesale trade the correlations remain positive in the 1990s. Crucially, these are the industries where, as seen earlier, the reallocation of market share is going in the wrong direction. Our reading of the combination of results in Table 4 and Table 5 is that relatively less efficient firms gained market share in several non-traded-goods sectors during the 1990s, and this process was facilitated by these firms gaining a rising share of bank lending.

\section{Conclusion}

The low pace of productivity growth in Japan's non-traded-goods sectors suggests considerable scope for "catch-up" in these industries and represents a potentially important source of future Japanese growth, but one that can be tapped only if the most inefficient firms in these industries close down or undergo substantial restructuring and the remaining firms work to improve performance.

The results of our study of Japanese firm-level data suggest that in some nontraded industries the allocation of market share is going in the wrong direction, adding to already poor productivity performance in these sector. One possible explanation is that inefficient firms are being sustained in part by financial support from Japanese banks. Thus, it seems clear that corporate restructuring needs to happen and is not coming about through competitive pressure. One policy implication is that banks should be provided incentives to withdraw this support and force these firms to meaningfully restructure or in some cases close. Such actions, however, would be unlikely outside of a more thorough 
reform of the financial sector, in part because if banks acknowledged the full extent of their non-performing loans problem, they may have to be recapitalized. 


\section{REFERENCES}

Ahearne, Alan G. et al. (2002) "Preventing Deflation: Lessons from Japan's Experience in the 1990s," International Finance Discussion Papers, 729, Board of Governors of the Federal Reserve System.

Atkeson, Andrew and Patrick J. Kehoe (1995) "Industry Evolution and Transition: Measuring Investment in Organizational Capital," Research Department Staff Report, 201, Federal Reserve Bank of Minneapolis.

Aw, Bee Yan, Xiaomin Chen, and Mark Roberts (1997) "Firm-Level Evidence on Productivity Differentials, Turnover and Export in Taiwanese Manufacturing," NBER Working Paper 6235.

Caballero, R., T. Hoshi and A Kashyap (2003) “Zombie Lending and Depresses Restructuring in Japan," Working Paper.

Caballero, R. and A. Kashyap (2002) “Japan's Indian Summer,” The Wall Street Journal, July 18.

Davis, Steven and John Haltiwanger (1999) “Gross Job Flows," in Ashenfelter, O. and D.Card, eds., Handbook of Labor Economics, Volume 3.

The Economist (2004) “Dead Firms Walking," Special report on Japan's service economy, September 25, 2004.

Feldman, R. (2002) “A Double Dip?” The Economist, August 17.

Foster, Lucia, John Haltiwanger, and C.J. Krizan (1998) "Aggregate Productivity Growth: Lessons from Microeconomic Evidence,” Working Paper.

Griliches, Zvi and Haim Regev (1995) "Firm Productivity in Israeli Industry: 19791988," Journal of Econometrics, 5 (1), 175-203.

Haltiwanger, J. (1997) "Measuring and Analyzing Aggregate Fluctuations: The Importance of Building from Microeconomic Evidence?" Federal Reserve Bank of St. Louis Review, May/June.

Haltiwanger, J. (2000) “Aggregate Growth: What Have We Learned from Microeconomic Evidence?” Working Paper.

Hayashi, F. and T. Inoue (1991) "The Relation Between Firm Growth and Q with Multiple Capital Goods: Theory and Evidence from a Panel Data on Japanese Firms," Econometrica, 59, 731-753. 
Hayashi, F. and E. Prescott (2002) “The 1990s in Japan: A Lost Decade,” Review of Economic Dynamics, January.

Hoshi, T. and A. Kashyap (1990) "Evidence on $q$ and Investment for Japanese Firms," Journal of the Japanese and International Economies, 4, 371-400.

Hoshi, Takeo and Anil Kashyap (2000) "The Japanese Banking Crisis: Where Did It Come From and How Will It End?" in Bernanke, Ben and Julio Rotemberg, eds., NBER Macroeconomics Annual, 14.

Katz, Richard (1998) “Japan: The System that Soured,” M.E. Sharpe, London.

Kawamoto, Takuji (2004) “What Do the Purified Solow Residuals Tell Us about Japan's Lost Decade?" Discussion Paper 2004-E-5, Institute for Monetary and Economic Studies, Bank of Japan.

Kim, Se-Jik (2003) "Macro Effects of Corporate Restructuring in Japan,” IMF Working Paper 203.

Lincoln, Edward J. (2001) "Arthritic Japan: The Slow Pace of Economic Reform," Brookings Institute, Washington, D.C.

Nagahata, Takashi and Toshitaka Sekine (2002) "The Effects of Monetary Policy of Firm Investment after the Collapse of the Asset Price Bubble: An Investigation Using Japanese Micro Data," Working Paper Series, 02-3, Research and Statistics Department, Bank of Japan.

Nishimura, K., T. Nakajima and K. Kiyota (2004) "Does the Natural Selection Mechanism Still Work in Severe Recessions?" Journal of Economic Behavior and Organization (forthcoming).

Peek, Joe and Eric Rosengren (2003) "Unnatural Selection: Perverse Incentives and the Misallocation of Credit in Japan," NBER Working Paper 9643, April.

Porter, M, H. Takeuchi and M. Sakakibara (2000) “Can Japan Compete?” Perseus, Massachusetts.

Shinada, Naoki (2003) "Decline in Productivity in Japan and Disparities Between Firms in the 1990s: An Empirical Approach Based on Data Envelopment Analysis," Research Report No. 38, Development Bank of Japan.

Smith, David C (2003) "Loans to Japanese Borrowers," Journal of the Japanese and International Economies vol. 17, September, pp. 283-304. 
Table 1

\section{Growth accounting}

\begin{tabular}{lcc}
\hline & & Average annual \\
\hline 1. Real GDP (percent change) & $1981-1990$ & $1991-2002$ \\
Contribution (percentage points): & 4.1 & 1.3 \\
2. Labor input (hours worked) & 0.7 & -0.7 \\
3. Labor productivity & 3.4 & 2.0 \\
4. Capital deepening $\quad 2.3$ & 1.9 \\
5. Multifactor productivity & 1.1 & 0.1 \\
\hline
\end{tabular}


Table 2

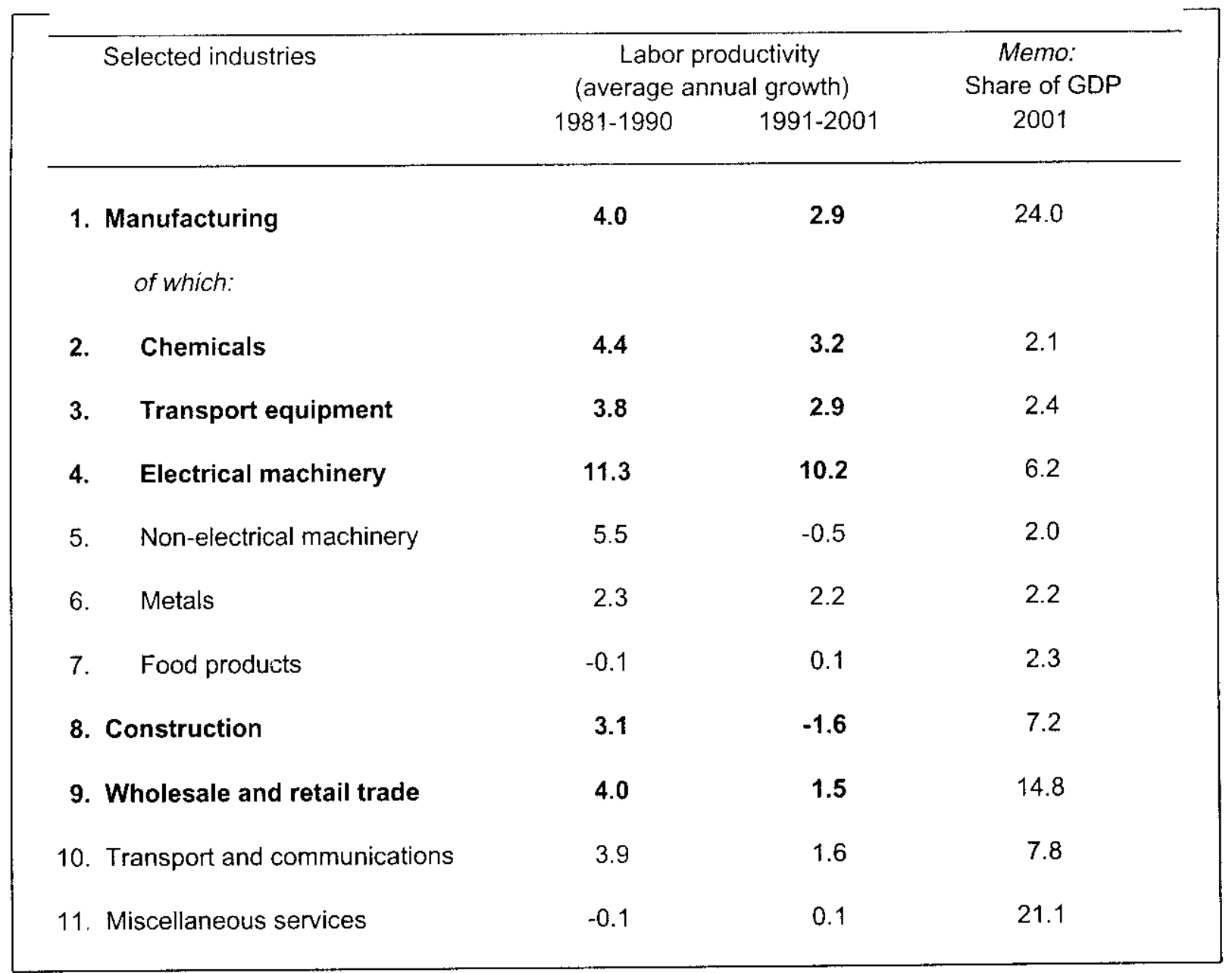


Table 3: Industry Growth

\begin{tabular}{|l|c|c|}
\hline a. Chemicals & \multicolumn{2}{|c|}{ Average annual \% change } \\
\hline & $1981-1990$ & $1991-2001$ \\
\hline 1. Real value added & 6.3 & 2.1 \\
\hline Contribution (percentage points): & & \\
\hline 2. Labor input (hours worked) & 0.2 & -2.3 \\
\hline 3. Labor productivity & 6.1 & 4.4 \\
\hline 4. Capital deepening & 3.8 & 2.6 \\
\hline 5. Multifactor productivity & 2.3 & 1.8 \\
\hline
\end{tabular}

\begin{tabular}{|c|c|c|}
\hline \multirow[t]{2}{*}{ b. Transport Equipment } & \multicolumn{2}{|c|}{ Average annual $\%$ change } \\
\hline & $1981-1990$ & $1991-2001$ \\
\hline 1. Real value added & 7.8 & 2.7 \\
\hline \multicolumn{3}{|c|}{ Contribution (percentage points): } \\
\hline 2. Labor input (hours worked) & 2.6 & -2.1 \\
\hline 3. Labor productivity & 5.2 & 4.8 \\
\hline 4. $\quad$ Capital deepening & 2.8 & 1.6 \\
\hline Multifactor productivity & 2.4 & 3.2 \\
\hline
\end{tabular}

\begin{tabular}{|c|c|c|}
\hline \multirow[t]{2}{*}{ c. Electrical Machinery } & \multicolumn{2}{|c|}{ Average annual \% change } \\
\hline & $1981-1990$ & $1991-2001$ \\
\hline 1. Real value added & 9.4 & 1.5 \\
\hline \multicolumn{3}{|c|}{ Contribution (percentage points): } \\
\hline 2. Labor input (hours worked) & 1.8 & -3.4 \\
\hline 3. Labor productivity & 7.6 & 4.9 \\
\hline 4. $\quad$ Capital deepening & 3.3 & 2.2 \\
\hline 5. Multifactor productivity & 4.3 & 2.7 \\
\hline
\end{tabular}

\begin{tabular}{|c|c|c|}
\hline \multirow[t]{2}{*}{ d. Precision Machinery } & \multicolumn{2}{|c|}{ Average annual \% change } \\
\hline & 1981-1990 & $1991-2001$ \\
\hline 1. Real value added & 6.1 & 1.9 \\
\hline \multicolumn{3}{|c|}{ Contribution (percentage points): } \\
\hline 2. Labor input (hours worked) & 3.3 & -2.5 \\
\hline 3. Labor productivity & 2.8 & 4.4 \\
\hline 4. Capital deepening & 3.5 & 2.5 \\
\hline 5. Multifactor productivity & -0.7 & 1.9 \\
\hline
\end{tabular}


Table 3: Industry Growth (continued)

\begin{tabular}{|l|c|c|}
\hline e. Food Products & \multicolumn{2}{|c|}{ Average annual \% change } \\
\hline & $1981-1990$ & $1991-2001$ \\
\hline 1. Real value added & 2.4 & -0.9 \\
\hline Contribution (percentage points): & & \\
\hline 2. Labor input (hours worked) & 1.3 & -1.8 \\
\hline 3. Labor productivity & 1.1 & 0.9 \\
\hline 4. Capital deepening & 1.8 & 1.4 \\
\hline 5. Multifactor productivity & -0.7 & -0.5 \\
\hline
\end{tabular}

\begin{tabular}{|l|c|c|}
\hline f. Textiles & \multicolumn{2}{c|}{ Average annual \% change } \\
\hline & $1981-1990$ & $1991-2001$ \\
\hline 1. Real value added & 3.3 & -3.1 \\
\hline Contribution (percentage points): & & \\
\hline 2. Labor input (hours worked) & -2.6 & -5.2 \\
\hline 3. Labor productivity & 5.9 & 2.1 \\
\hline 4. Capital deepening & 3.5 & 2.5 \\
\hline 5. Multifactor productivity & 2.4 & -0.4 \\
\hline
\end{tabular}

\begin{tabular}{|l|c|c|}
\hline g. Iron and Steel & \multicolumn{2}{|c|}{ Average annual \% change } \\
\hline & $1981-1990$ & $1991-2001$ \\
\hline 1. Real value added & 0.3 & -4.9 \\
\hline Contribution (percentage points): & & \\
\hline 2. Labor input (hours worked) & -4.1 & -5.1 \\
\hline 3. Labor productivity & 4.4 & 0.2 \\
\hline 4. Capital deepening & 3.3 & 1.8 \\
\hline 5. Multifactor productivity & 1.1 & -1.6 \\
\hline
\end{tabular}

\begin{tabular}{|l|c|c|}
\hline h. Construction (Civil Engineering) & \multicolumn{2}{|c|}{ Average annual \% change } \\
\hline & $1981-1990$ & $1991-2001$ \\
\hline 1. Real value added & 5.2 & 0.0 \\
\hline Contribution (percentage points): & & \\
\hline 2. Labor input (hours worked) & 0.0 & -1.3 \\
\hline 3. Labor productivity & 5.2 & 1.3 \\
\hline 4. Capital deepening & 1.6 & 0.9 \\
\hline 5. Multifactor productivity & 3.6 & 0.4 \\
\hline
\end{tabular}


Table 3: Industry Growth (continued)

\begin{tabular}{|l|c|c|}
\hline i. Construction (Other) & \multicolumn{2}{|c|}{ Average annual \% change } \\
\hline & $1981-1990$ & $1991-2001$ \\
\hline 1. Real value added & 3.6 & -0.5 \\
\hline Contribution (percentage points): & & \\
\hline 2. Labor input (hours worked) & -0.8 & -1.4 \\
\hline 3. Labor productivity & 4.4 & 0.9 \\
\hline 4. Capital deepening & 1.5 & 0.1 \\
\hline 5. Multifactor productivity & 2.9 & 0.8 \\
\hline
\end{tabular}

\begin{tabular}{|l|c|c|}
\hline j. Retail Trade & \multicolumn{2}{c|}{ Average annual \% change } \\
\hline & $1981-1990$ & $1991-2001$ \\
\hline 1. Real value added & 3.6 & -1.5 \\
\hline Contribution (percentage points): & & \\
\hline 2. Labor input (hours worked) & 1.3 & -2.9 \\
\hline 3. Labor productivity & 2.3 & 1.4 \\
\hline 4. Capital deepening & 1.7 & 1.3 \\
\hline 5. Multifactor productivity & 0.6 & 0.1 \\
\hline
\end{tabular}

\begin{tabular}{|l|c|c|}
\hline k. Wholesale Trade & \multicolumn{2}{|c|}{ Average annual \% change } \\
\hline & $1981-1990$ & $1991-2001$ \\
\hline 1. Real value added & 4.7 & 1.2 \\
\hline Contribution (percentage points): & & \\
\hline 2. Labor input (hours worked) & 0.6 & -1.9 \\
\hline 3. Labor productivity & 4.1 & 3.1 \\
\hline 4. Capital deepening & 2.2 & 1.4 \\
\hline 5. Multifactor productivity & 1.9 & 1.7 \\
\hline
\end{tabular}

\begin{tabular}{|l|c|c|}
\hline 1. Cargo Road Transport & \multicolumn{2}{|c|}{ Average annual \% change } \\
\hline & $1981-1990$ & $1991-2001$ \\
\hline 1. Real value added & 3.8 & 1.8 \\
\hline Contribution (percentage points): & & \\
\hline 2. Labor input (hours worked) & 2.6 & 2.7 \\
\hline 3. Labor productivity & 1.2 & -0.9 \\
\hline 4. Capital deepening & 0.8 & -0.5 \\
\hline 5. Multifactor productivity & 0.4 & -0.4 \\
\hline
\end{tabular}


Table 4: Results of Decomposition

\begin{tabular}{|l|c|c|}
\hline a. Chemicals & \multicolumn{2}{|c|}{ Average annual \% change } \\
\hline & $1981-1990$ & $1991-2001$ \\
\hline 1. Multifactor productivity & 2.8 & 2.2 \\
\hline Contribution (percentage points): & & \\
\hline 2. "Within" component & 2.0 & 1.4 \\
\hline 3. "Between" component & 0.1 & 0.0 \\
\hline 4. "Covariance" component & 0.7 & 0.8 \\
\hline
\end{tabular}

\begin{tabular}{|l|c|c|}
\hline b. Transport Equipment & \multicolumn{2}{|c|}{ Average annual \% change } \\
\hline & $1981-1990$ & $1991-2001$ \\
\hline 1. Multifactor productivity & 1.8 & 3.9 \\
\hline Contribution (percentage points): & & \\
\hline 2. "Within" component & 1.5 & 3.3 \\
\hline 3. "Between" component & 0.1 & 0.2 \\
\hline 4. "Covariance" component & 0.2 & 0.4 \\
\hline
\end{tabular}

\begin{tabular}{|l|c|c|}
\hline c. Electrical Machinery & \multicolumn{2}{|c|}{ Average annual \% change } \\
\hline & $1981-1990$ & $1991-2001$ \\
\hline 1. Multifactor productivity & 4.1 & 4.3 \\
\hline Contribution (percentage points): & & \\
\hline 2. "Within" component & 3.5 & 3.7 \\
\hline 3. "Between" component & 0.1 & 0.1 \\
\hline 4. "Covariance" component & 0.5 & 0.5 \\
\hline
\end{tabular}

\begin{tabular}{|l|c|c|}
\hline d. Precision Machinery & \multicolumn{2}{|c|}{ Average annual \% change } \\
\hline & $1981-1990$ & $1991-2001$ \\
\hline 1. Multifactor productivity & -0.7 & 2.0 \\
\hline Contribution (percentage points): & & \\
\hline 2. "Within" component & -0.6 & 1.6 \\
\hline 3. "Between" component & -0.2 & 0.0 \\
\hline 4. "Covariance" component & 0.1 & 0.4 \\
\hline
\end{tabular}


Table 4: Results of Decomposition (continued)

\begin{tabular}{|l|c|c|}
\hline e. Food Products & \multicolumn{2}{|c|}{ Average annual \% change } \\
\hline & $1981-1990$ & $1991-2001$ \\
\hline 1. Multifactor productivity & -0.5 & -0.3 \\
\hline \multicolumn{1}{|c|}{ Contribution (percentage points): } & -0.6 & \\
\hline 2. "Within" component & 0.0 & -0.5 \\
\hline 3. "Between" component & 0.1 & 0.0 \\
\hline 4. "Covariance" component & 0.2 \\
\hline
\end{tabular}

\begin{tabular}{|l|c|c|}
\hline f. Textiles & \multicolumn{2}{|c|}{ Average annual \% change } \\
\hline & $1981-1990$ & $1991-2001$ \\
\hline 1. Multifactor productivity & 2.1 & -0.4 \\
\hline \multicolumn{1}{|c|}{ Contribution (percentage points): } & & \\
\hline 2. "Within" component & 2.2 & -0.4 \\
\hline 3. "Between" component & 0.0 & 0.0 \\
\hline 4. "Covariance" component & -0.1 & 0.0 \\
\hline
\end{tabular}

\begin{tabular}{|l|c|c|}
\hline g. Iron and Steel & \multicolumn{2}{|c|}{ Average annual \% change } \\
\hline & $1981-1990$ & $1991-2001$ \\
\hline 1. Multifactor productivity & 1.3 & -1.8 \\
\hline \multicolumn{1}{|c|}{ Contribution (percentage points): } & & \\
\hline 2. "Within" component & 1.1 & -1.7 \\
\hline 3. "Between" component & 0.1 & 0.1 \\
\hline 4. "Covariance" component & 0.1 & -0.2 \\
\hline
\end{tabular}

\begin{tabular}{|l|c|c|}
\hline h. Construction (Civil Engineering) & \multicolumn{2}{|c|}{ Average annual \% change } \\
\hline & $1981-1990$ & $1991-2001$ \\
\hline 1. Multifactor productivity & 3.2 & -0.4 \\
\hline \multicolumn{1}{|c|}{ Contribution (percentage points): } & 2.2 & \\
\hline 2. "Within" component & 0.3 & -0.2 \\
\hline 3. "Between" component & 0.7 & -0.1 \\
\hline 4. "Covariance" component & \\
\hline
\end{tabular}


Table 4: Results of Decomposition (continued)

\begin{tabular}{|l|c|c|}
\hline i. Construction (Other) & \multicolumn{2}{|c|}{ Average annual \% change } \\
\hline & $1981-1990$ & $1991-2001$ \\
\hline 1. Multifactor productivity & 2.9 & 0.2 \\
\hline \multicolumn{1}{|c|}{ Contribution (percentage points): } & & \\
\hline 2. "Within" component & 2.6 & 0.7 \\
\hline 3. "Between" component & 0.0 & -0.3 \\
\hline 4. "Covariance" component & 0.3 & -0.2 \\
\hline
\end{tabular}

\begin{tabular}{|l|c|c|}
\hline j. Retail Trade & \multicolumn{2}{|c|}{ Average annual \% change } \\
\hline & $1981-1990$ & $1991-2001$ \\
\hline 1. Multifactor productivity & 0.3 & 0.1 \\
\hline \multicolumn{1}{|c|}{ Contribution (percentage points): } & & \\
\hline 2. "Within" component & 0.2 & 0.3 \\
\hline 3. "Between" component & 0.0 & 0.0 \\
\hline 4. "Covariance" component & 0.1 & -0.2 \\
\hline
\end{tabular}

\begin{tabular}{|l|c|c|}
\hline k. Wholesale Trade & \multicolumn{2}{|c|}{ Average annual \% change } \\
\hline & $1981-1990$ & $1991-2001$ \\
\hline 1. Multifactor productivity & 1.7 & 1.4 \\
\hline \multicolumn{1}{|c|}{ Contribution (percentage points): } & & \\
\hline 2. "Within" component & 1.6 & 1.5 \\
\hline 3. "Between" component & 0.1 & 0.0 \\
\hline 4. "Covariance" component & 0.0 & -0.1 \\
\hline
\end{tabular}

\begin{tabular}{|l|c|c|}
\hline I. Cargo Road Transport & \multicolumn{2}{|c|}{ Average annual \% change } \\
\hline & $1981-1990$ & $1991-2001$ \\
\hline 1. Multifactor productivity & 0.2 & -0.2 \\
\hline \multicolumn{1}{|c|}{ Contribution (percentage points): } & & \\
\hline 2. "Within" component & 0.0 & 0.1 \\
\hline 3. "Between" component & 0.1 & 0.1 \\
\hline 4. "Covariance" component & 0.1 & -0.4 \\
\hline
\end{tabular}


Table 5: Correlations*

\begin{tabular}{|l|c|c|}
\hline Industry & $\mathbf{1 9 8 0 - 1 9 9 0}$ & $\mathbf{1 9 9 1 - 2 0 0 1}$ \\
\hline Chemicals & 0.75 & 0.08 \\
\hline Transport Equipment & 0.17 & -0.45 \\
\hline Electrical Machinery & 0.66 & -0.59 \\
\hline Precision Machinery & 0.63 & -0.51 \\
\hline Food Products & -0.08 & -0.05 \\
\hline Textiles & -0.61 & -0.87 \\
\hline Iron and Steel & -0.13 & -0.25 \\
\hline Construction (Civil Engineering) & -0.85 & 0.18 \\
\hline Construction (Other) & 0.10 & 0.27 \\
\hline Retail Trade & 0.43 & 0.29 \\
\hline Wholesale Trade & 0.61 & 0.33 \\
\hline Cargo Road Transport & 0.88 & -0.51 \\
\hline
\end{tabular}

*Correlations between changes in market share and changes in share of outstanding bank loans. 
Figure 1

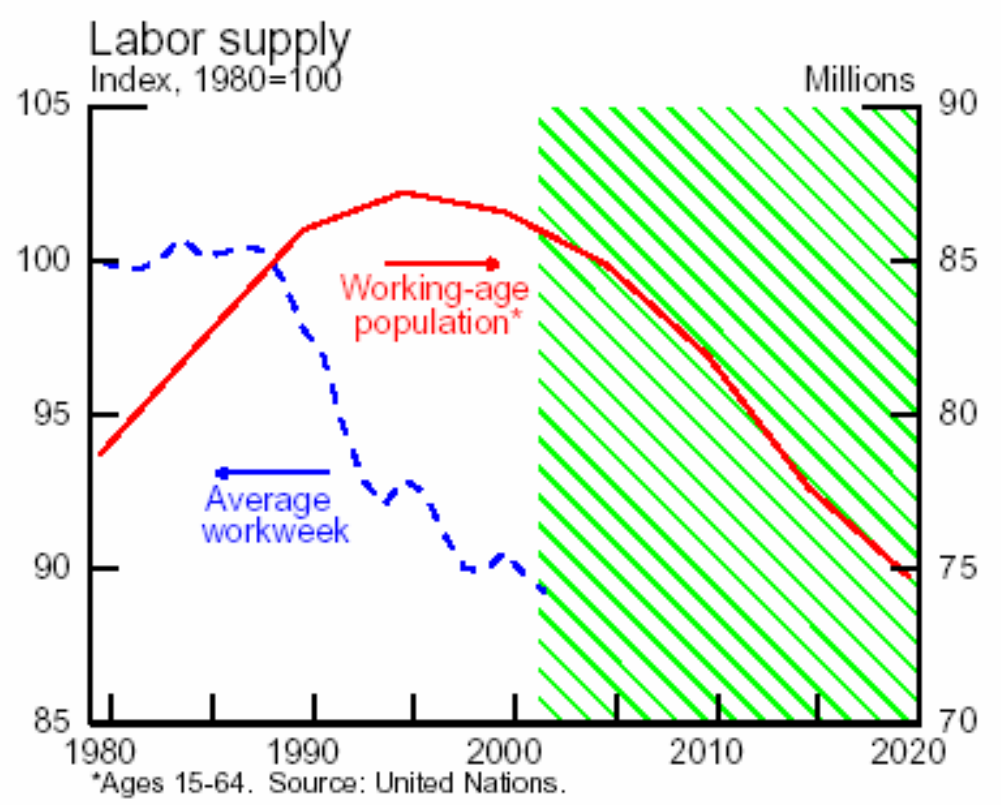

Figure 2

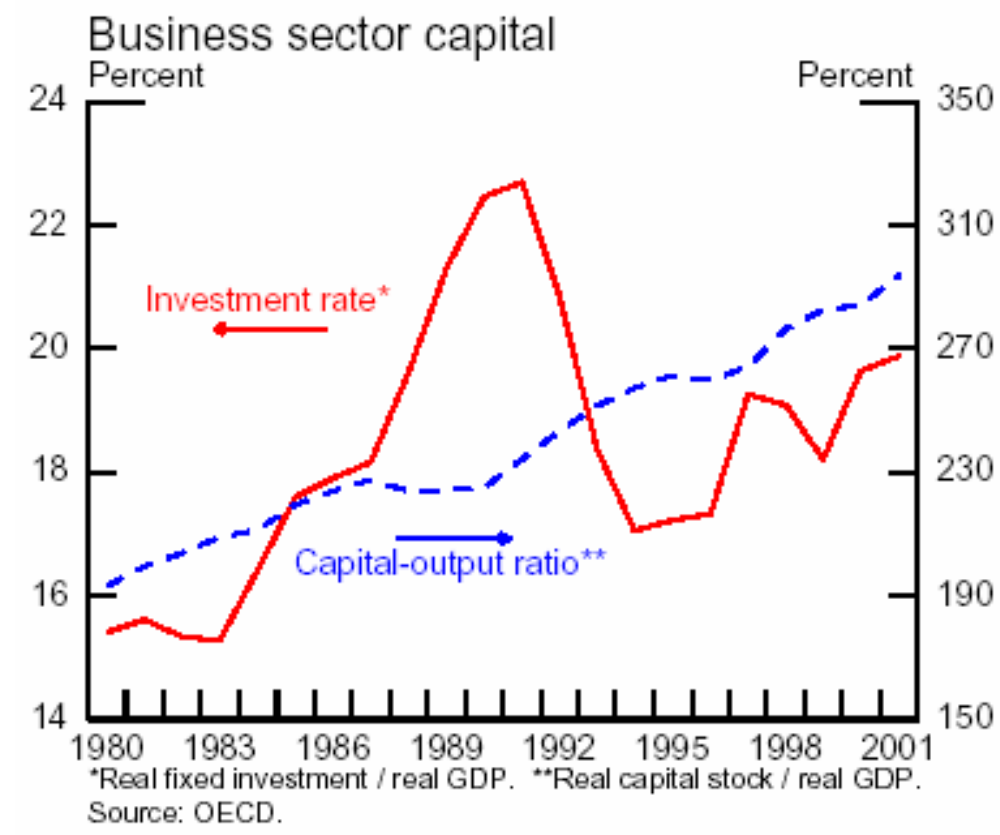


Figure 3

\section{Bank loans outstanding}

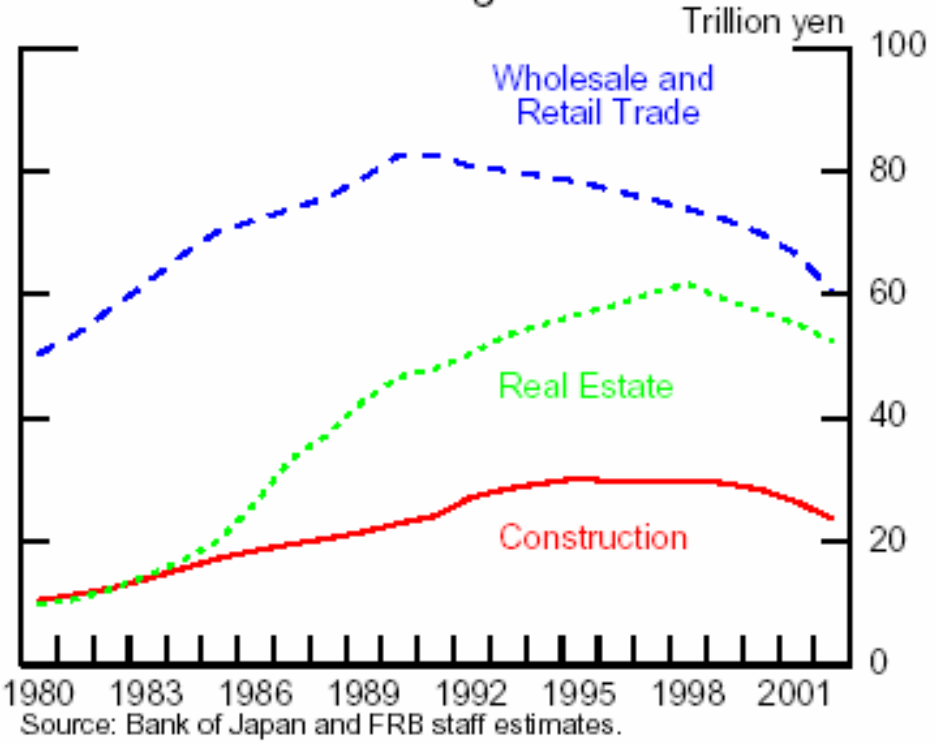

Figure 4

\section{Contributions to Labor Productivity Growth}

Selected industries: 1991-2001

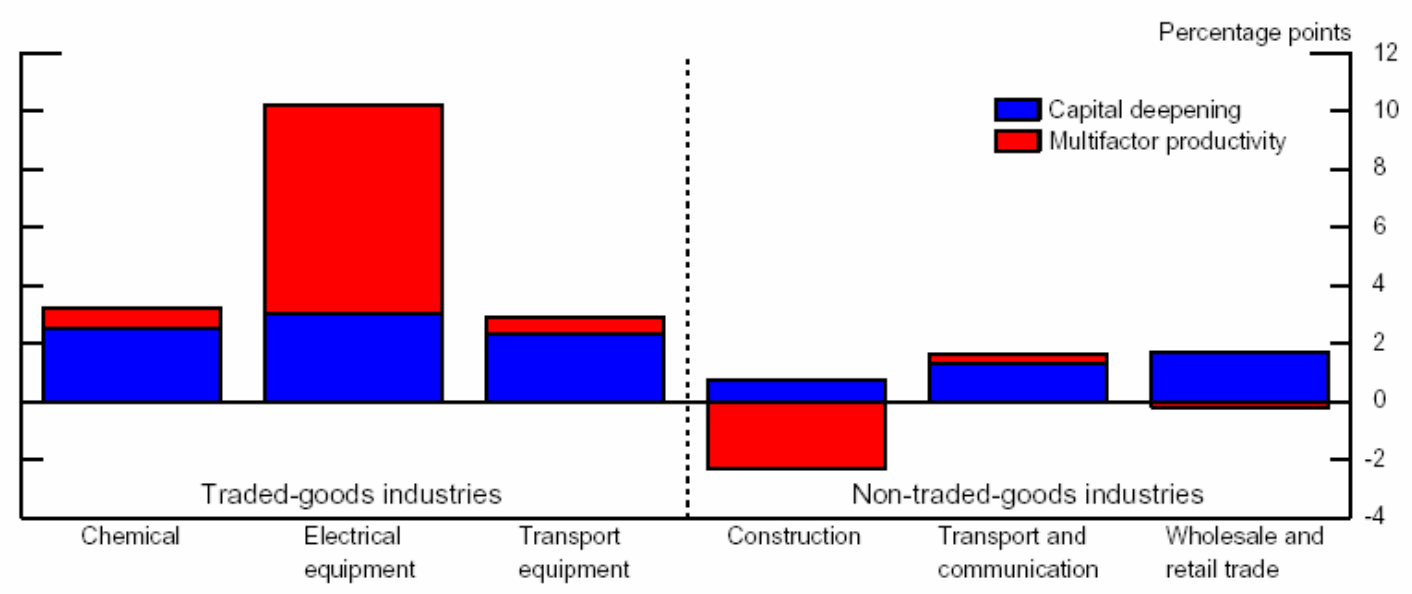


Figure 5: Total borrowings by industry

(yen billions)
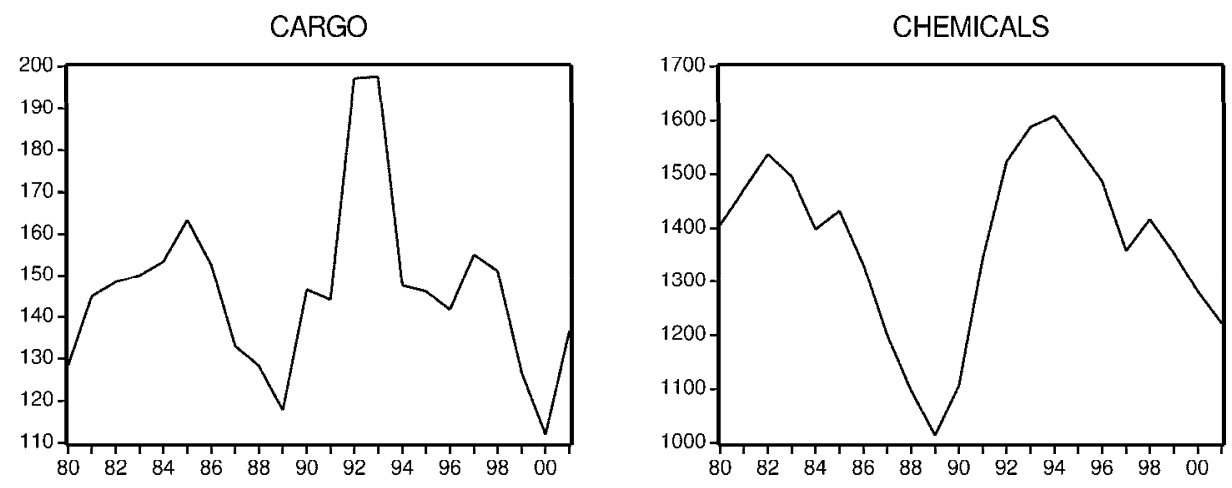

CIVIL
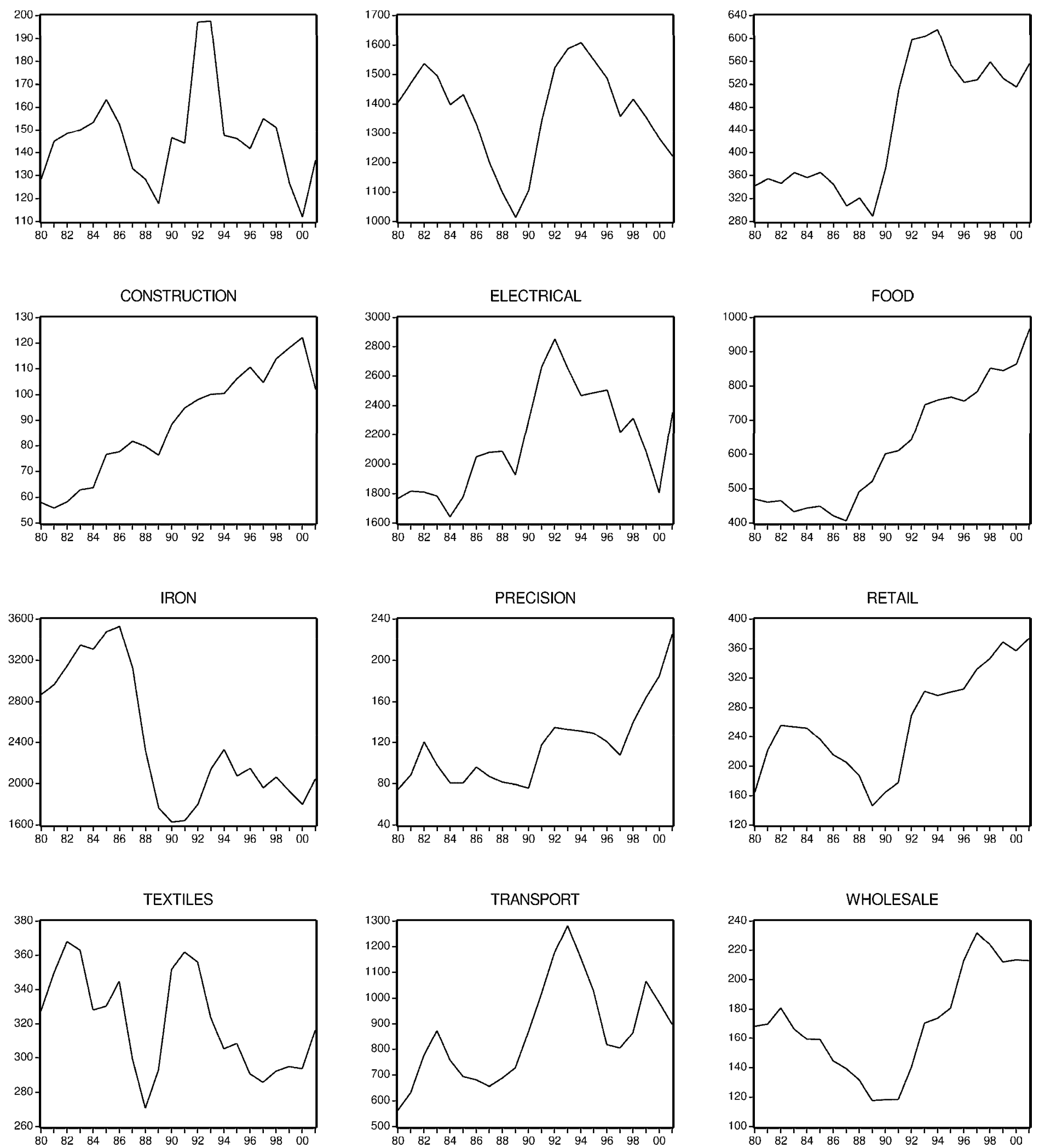